\title{
Adopting the Diversity Management Approach. Case of Slovakia.
}

\author{
Tomas Michalicka ${ }^{1 *}$, Drahoslav Lancaric ${ }^{1}$, and Hana Zach $^{2}$ \\ ${ }^{1}$ Slovak University of Agriculture in Nitra, Faculty of Economics and Management, Department of \\ Management, Trieda A. Hlinku 2, 94976 Nitra, Slovakia \\ ${ }^{2}$ Slovak University of Agriculture in Nitra, Faculty of Economics and Management, Department of \\ Statistics and Operational Research, Trieda A. Hlinku 2, 94976 Nitra, Slovakia
}

\begin{abstract}
.
Research background: Towards the end of the previous century the issue of management of diversity in organisations gained a prominent place in both academic and societal debates. For any multicultural country, such as the United States or Great Britain, the issue of diversity is not new. However, diversity has not been as frequently researched in the countries of the Visegrad region: the Slovak Republic, the Czech Republic, Poland and Hungary.

Purpose of the article: Using the data about 278 business organizations in Slovakia, we focus on the background of the implementation of diversity management from the point of view of factors having a direct influence on this process. We evaluate the influence of the legal form (as an expression of the number of owners and the ability to quickly adopt a new concept) of the business organisation, the size (number of employees) of the business organisation, the share of the foreign capital in the ownership structure of the organisations, the sector of economy the organization operates in, its performance and the existence of HR unit in the organizational structure.

Methods: To evaluate the influence of the selected factors linear modelling was used.

Findings \& Value added: The study theoretically contributes to human resource management, talent management and organizational behaviour theories, and offers several policy implications for decision makers. Specifically, it deals with the relationship between the implementation of the diversity management selected organizations` characteristics.
\end{abstract}

Keywords: workforce diversity; diversity management; implementation factors; organizational performance

JEL Classification: $M 12 ; M 51 ; M 53 ; O 34$

\footnotetext{
* Corresponding author: xmichalicka@uniag.sk
} 


\section{Introduction}

Towards the end of the previous century the issue of diversity in organisations gained a prominent place in both academic and societal debates. Within the discussions over the past decades concerning diversity issues in organisations, we particularly note a struggle in relation to sameness and difference. Diversity can be defined as a mix of differences, similarities, and tensions that can exist among the elements of a collective mixture. Diversity or heterogeneity may be understood from the point of view of certain criteria or dimensions.

Because globalisation and migration allowed for a more mixed workforce, scholars began researching the potential benefits of diversity as a business case with a focus on the organisational performance. The diverse workplace requires employees to possess the relevant knowledge, skills, abilities, and attitudes to effectively interact with colleagues, customers, and clients who are different from themselves. There has been a surge in research on how work teams should be composed to foster high levels of performance. Many companies take different measures to better handle diversity, seeing an opportunity to enhance their future growth and to develop a competitive advantage. The range of potential business advantages for diversity has been supported by several authors, who suggest that increased diversity can lead to a better understanding of local markets and customers, increased ability to attract and retain the best people, greater creativity, better problem solving and greater flexibility for organisations.

In the paper, we focus on the background of the implementation of diversity management from the point of view of factors having a direct influence on this process. We evaluate the influence of the legal form (as an expression of the number of owners and the ability to quickly adopt a new concept) of the business organisation, the size (number of employees) of the business organisation, the share of the foreign capital in the ownership structure of the organisations and its economic situation (both its development and result).

\section{Literature review}

\subsection{Diversity definitions}

From a company point of view, diversity means the co-existence of employees from various socio-cultural backgrounds. Primary cultural factors of diversity are considered gender, race, age, color, ethnicity, etc. From broader perspective, as diversity factors can be mentioned also national origin, religion, disability, sexual orientation, values, ethnic culture, education, language, lifestyle, beliefs, economic status and physical appearance [1]. If workforce diversity should be beneficial for a company, it needs to be supported by a company culture, where all employees can pursue their career aspirations without being inhibited by gender, race, nationality, religion, or other factors that are irrelevant to their performance [2].

Torres and Bruxelles [3] are describing managing diversity as enabling the diverse workforce to perform its full potential in an equitable work environment where no one group has an advantage or disadvantage. According to [4] diversity management has been historically adopted by many companies just as a potential proof that organization cannot be accused from employees' discrimination, but in recent years this diversity management concept has significantly changed to a more proactive one as more and more business leaders nowadays really believe in bottom-line benefits of diversity.

According to [5], diversity management practices are dealing with two fundamental questions. First, how to implement measures, that will make the workforce of an organization more diverse. Second, how to make the workplace as inclusive as possible. One of the ways 
how to make diversity management works in a company is to implement it through diversity networks. These in-company networks are created to inform, support and advance employees with marginalized social identities [6]. Diversity networks offer to their employee-members useful tools for career development, they are building communities between employees with similar social identities and last, but not least, pertaining inclusion [7].

\subsection{Diversity management benefits}

Throughout the years, there have been many studies and researches presenting workforce diversity and active diversity management as competitive advantage for organizations. Already in early 1990s, Cox and Blake [8], as potential diversity benefits, outlined better decision making, higher innovation and creativity, more successful marketing to domestic and foreign ethnic minority communities, and a better distribution of economic opportunity. Allen et al. [4] are also advocating workforce diversity as a competitive advantage for a company, because they think that different perspectives can facilitate unique and creative approaches to problem-solving, thereby increasing creativity and innovation, which consequently can lead to better performance. Active and effective diversity management within company can lead to positive outcomes, because it could create a social exchange relationship with minority employees. This is because, adopting diversity management practices demonstrates an organization's effort to support diversity. Subsequently, the perception that an organization supports diversity could create a feeling of attachment to the organization and it positively influences ethnic and minority employees' turnover intent and career satisfaction [9]. Diversity could have positive impact also on performance. According to study performed by Watson et al. [10], culturally diverse teams comparing to homogeneous teams are more effective in their job performance, but only under the condition, that these diverse teams have been working together for longer time.

Another area of diversity benefits, especially for large organizations and international multicultural corporations are diverse board members and diverse top management teams. Results of a study performed by Saona, Muro and San Martín [11] confirm the benefits of having a balanced board in terms of gender diversity and the relevance of legislation concerning the application of female quotas on boards in Europe. Specifically, their results show that having a balanced board between men and women directors is reducing and partially mitigating earning management practices. This benefit is even stronger in countries that have required female quotas on board of directors, where the outcome has led to less earnings manipulations and more informative financial statements. Diversity in the board of directors leads to reduced stock return volatility, adoption of more stable and persistent company policies and more investments in R\&D. Net benefits can be summarized as higher profitability and firm valuations [12]. Companies should promote gender diversity and foreign participation at board level, because it has a positive and significant impact on firm performance. In this respect, board diversity has an impact on firm value, and specifically, in the case of listed companies, the more diversified a board is, the higher the firm performance will be [13]. Greater board diversity can lower the risk of future stock crash. Diverse board can curb managerial incentive to suppress bad-news and thus reduce crash risk. This effect of board diversity on future crash risk is stronger for firms with high information opacity and low institutional ownership [14].

Graafland [15] is focusing on gender diversity specifically in SMEs management. Based on his findings, increasing the gender diversity in SMEs management is improving the sustainability of SMEs, which increases their shared value by bettering reputation. SMEs sustainable performance should be optimal, when the share of women in management equals to $54 \%$. 


\subsection{Diversity management limitations}

As it was described in the previous paragraph, diversity can bring many potential benefits to organizations, but mostly in a case, it is actively managed. In this respect, probably one of the main reasons, why many companies still haven't implemented active diversity management, even they are aware about these benefits, are costs associated with active diversity management. These costs are mainly connected with seminars, programs and lectures for promoting diversity in company. Adequate training should be delivered to employees on all levels within the organization, in order to effectively implement diversity management and leverage its positive impact on company [16]. Implementation of diversity management practices does not automatically ensure positive results for companies. Intention, why they are doing so is also important. Findings of a study performed by OtayeEbede and Lilian [9] shows that when employees perceive that diversity management practices are driven not by a concern for employees but by an equality-driven compliance focus (legal reasons and political correctness), there is an increased level of turnover intention.

Workforce diversity is sometimes metaphorically called as double-edged sword. On the one hand, it can have positive impact on the company, but on the other hand, diversity can also result into increase of conflicts in the workplace. The most common conflicts come from one feeling superior. And if management ignores such conflicts, the company's performance may suffer as well [16]. Similar opinion regarding diversity disadvantage is provided by Goetz [17], who arguments that mismanaged diversity can have long effects on satisfaction and productivity of employees. He explains, that denied access or unfavourable treatment can bring negative consequences, such as inhibiting workers' abilities and motivation, which leads to lower performance on the job.

With the focus on the board diversity, disadvantage of diverse board of directors is slower response time, comparing to homogeneous groups. This can be critical especially when company must react quickly to new information, which can have higher negative impact either on highly specialized firms or on organizations operating under highly volatile market conditions [12].

\section{Methodology}

All data for the research were collected between May and September 2018. 278 business organizations in Slovakia participated in the research. Data were collected both personally and via on-line form.

The questionnaire was divided into two parts. The first part was focused on classification items, the task of which was to determine the size of the business entity expressed by the number of employees; legal form of the company; the sector of the national economy in which the company operates; the share of foreign capital in its ownership structure; change of the overall economic situation of the company compared to the previous year; overall economic performance from the perspective of loss or profit and existence of HR unit within organisational structure of the company. The second part of the questionnaire was oriented on the implementation of diversity management. The focus was on the following six elements: benefits, implementation, implementation problems, work climate, special needs and Benefits Quantification Problems. All six elements were identified using factor analysis. The suitability of applying the factor analysis was verified based on Kaiser-Meyer-Olkin Measure of Sampling Adequacy (KMO test) and Bartlett's test of sphericity. The results of both testing statistical methods were satisfactory (Bartlett's test: $\mathrm{p}<0.05$; KMO test $>0.7$ $(0.841))$. The assumptions for applying the factor analysis were met. The factor analysis 
identified 6 background factors which altogether explained over $70 \%$ of the total variance $(72.33 \%)$.

Operationalisation of variables is explained in table 1.

Table 1. Operationalisation of the Variables

\begin{tabular}{|c|c|c|c|}
\hline Variable & Coding & & Measurement \\
\hline Size of the company & NUM_EMPLOY & & $\begin{array}{l}1=10 \text { and less; } \\
2=\text { from } 11 \text { to } 50 ; \\
3=\text { from } 51 \text { to } 250 ; \\
4=\text { over } 250\end{array}$ \\
\hline Legal form of the company & LEGAL_F & & $\begin{array}{l}\text { 1=personal } \\
\text { company; } 2=\text { limited } \\
\text { liability company; } \\
3=\text { joint-stock } \\
\text { company; } \\
\text { 4=cooperative; } \\
\text { 5=other }\end{array}$ \\
\hline $\begin{array}{l}\text { Sector of the national } \\
\text { economy the company } \\
\text { operates in }\end{array}$ & SECTOR & & $\begin{array}{l}1=\text { primary; } \\
2=\text { secondary; } \\
3=\text { services; } 4=\text { public }\end{array}$ \\
\hline $\begin{array}{l}\text { Share of foreign capital in } \\
\text { the ownership structure }\end{array}$ & FOR_CAP & & $\begin{array}{l}1=0 \% \text { (domestic); } \\
2=1 \%-40 \% ; 3=\text { over } \\
40 \%\end{array}$ \\
\hline $\begin{array}{l}\text { Change of the overall } \\
\text { economic situation of the } \\
\text { company compared to the } \\
\text { previous year }\end{array}$ & ECON_SIT & & $\begin{array}{l}1=\text { worse; } 2=\text { better; } \\
3=\text { =the same }\end{array}$ \\
\hline $\begin{array}{l}\text { Final economic } \\
\text { performance of the } \\
\text { company }\end{array}$ & LOSS/PROF & & $1=$ loss $; 2=$ profit \\
\hline $\begin{array}{l}\text { HR unit in the } \\
\text { organisational structure of } \\
\text { the company }\end{array}$ & HR_UNIT & & $1=$ yes; $2=$ no \\
\hline Diversity Policy: Benefits & DP_B & I_15 - I_22 & $\begin{array}{l}\text { likert scale, 1-totally } \\
\text { disagree, 7-totally } \\
\text { agree; average score }\end{array}$ \\
\hline $\begin{array}{l}\text { Diversity Policy: } \\
\text { Implementation }\end{array}$ & DP_I & I_1 - I_7, I_10 & $\begin{array}{l}\text { likert scale, 1-totally } \\
\text { disagree, } 7 \text {-totally } \\
\text { agree; average score }\end{array}$ \\
\hline $\begin{array}{l}\text { Diversity Policy: } \\
\text { Implementation problems }\end{array}$ & DP_IP & I_26 - I_32 & $\begin{array}{l}\text { likert scale, } 1 \text {-totally } \\
\text { disagree, } 7 \text {-totally } \\
\text { agree; average score }\end{array}$ \\
\hline $\begin{array}{l}\text { Diversity Policy: Work } \\
\text { climate }\end{array}$ & DP_WC & I_23 - I_25 & $\begin{array}{l}\text { likert scale, } 1 \text {-totally } \\
\text { disagree, } 7 \text {-totally } \\
\text { agree; average score }\end{array}$ \\
\hline $\begin{array}{l}\text { Diversity Policy: Special } \\
\text { needs }\end{array}$ & DP_SN & I_8I_9, I_11, I_12, I_13, I_14 & $\begin{array}{l}\text { likert scale, 1-totally } \\
\text { disagree, 7-totally } \\
\text { agree; average score }\end{array}$ \\
\hline $\begin{array}{l}\text { Diversity Policy: Benefits } \\
\text { Quantification Problems }\end{array}$ & DP_BQP & I_33, I_34 & $\begin{array}{l}\text { likert scale, 1-totally } \\
\text { disagree, 7-totally } \\
\text { agree; average score }\end{array}$ \\
\hline
\end{tabular}

Used questionnaire was constructed by the authors. Its reliability was verified through Cronbach`s Alpha (table 2). Values above 0.7 indicate good validity of the measurement tool [18]. All six thematic areas of the questionnaire reached the value of Cronbach' Alpha above 0.7 which means that the overall reliability is satisfying. The Intraclass Correlation Coefficient also confirmed this conclusion. Items in the questionnaire were scaled, using a seven-point Likert scale (from 1 to 7), where the value of 1 corresponded to the absolute disagreement of the respondent with the statement stated in item, a value of 4 expressed his 
neutral stance and a value of 7 corresponded to his absolute consent. Given the scale, therefore, the higher achieved average score in the given item means a higher degree of respondents' agreement with the statement stated in the item questionnaire.

Table 2. Questionnaire reliability analysis

\begin{tabular}{|l|c|c|}
\hline & N of Items & Cronbach's Alpha \\
\hline DP: benefits & 8 & 0.916 \\
\hline DP: implementation & 8 & 0.764 \\
\hline DP: work climate & 3 & 0.874 \\
\hline DP: Special needs & 6 & 0.722 \\
\hline DP: Implementation problems & 7 & 0.757 \\
\hline DP: benefits quantification problems & 2 & 0.724 \\
\hline Total & $\mathbf{3 4}$ & $\mathbf{0 . 8 6 7}$ \\
\hline
\end{tabular}

To examine the effect of selected background factors (the size of the organization in terms of number of employees (NUM_EMPLOY); the legal form of the company (LEGAL_F); the sector of the national economy the company operates in (SECTOR); the share of foreign capital in the ownership structure (FOR_CAP), the change of the overall economic situation of the company compared to the previous year (ECON_SIT); the final economic performance of the company (LOSS/PROF) and the existence of $\overline{\mathrm{HR}}$ unit in the organisational structure of the company (HR_UNIT)) on the aspects of the implementation of diversity management in the company the linear regression was used. The functional form of regression is as follows:

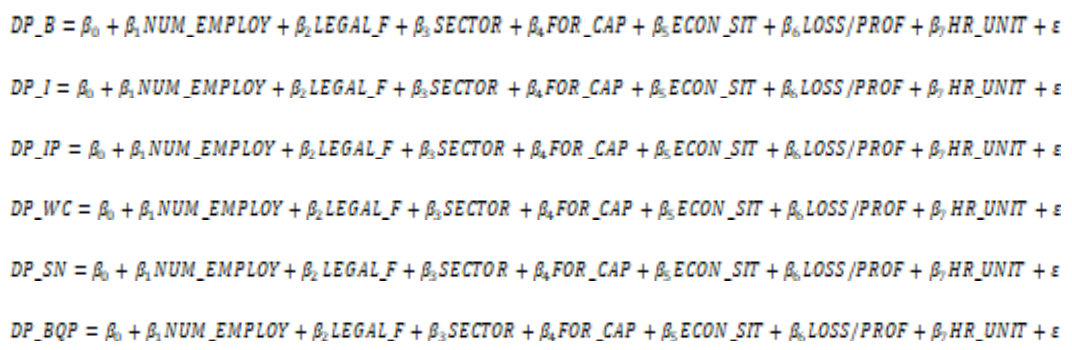

\section{Results}

On the research participated 278 companies in Slovakia. From the size of the company perspective, there were not significant differences between companies as in the most prevailing group were companies from 11 to 50 employees representing $31.7 \%$ of respondents and on the other side companies with 10 and less employees represented $19.4 \%$. More than $50 \%$ of companies didn't have any share of foreign capital in their ownership structure, while the remaining two categories (below and over $40 \%$ of foreign capital) were equally represented by $24.5 \%$ of respondents. Most of the companies participating on the research were limited liability companies $(56.8 \%)$ and only $5 \%$ can be classified as personal company. Overall economic situation comparing to previous year was the same in the case of most of the companies (almost 60\%), remaining 26.6\% of companies were in better economic situation and $14 \%$ in a worse. Only $12.9 \%$ of companies ended in net loss position while $87.1 \%$ were profitable. HR department was established in $66.5 \%$ of companies, the remaining $33.5 \%$ of companies did not have any HR unit within their organizational structure (table 3). 
Table 3. Characteristics of the research sample

\begin{tabular}{|c|c|c|c|c|c|}
\hline NUM_EMPLOY & $\%$ & LEGAL_F & $\%$ & SECTOR & $\%$ \\
\hline 10 and less & 19.4 & personal company & 5.0 & primary & 14.0 \\
\hline 11 to 50 & 31.7 & limited liability company & 56.8 & secondary & 25.9 \\
\hline 51 to 250 & 22.3 & joint-stock company & 20.1 & services & 54.3 \\
\hline over 250 & 26.6 & cooperative & 4.3 & public & 5.8 \\
\hline FOR_CAP & $\%$ & other & 13.7 & LOSS/PROF & $\%$ \\
\hline $0 \%$ & 51.1 & ECON_SIT & $\%$ & loss & 12.9 \\
\hline $1 \%-40 \%$ & 24.5 & worse & 14.0 & profit & 87.1 \\
\hline \multirow[t]{3}{*}{ over $40 \%$} & 24.5 & better & 26.6 & HR_UNIT & $\%$ \\
\hline & & no change & 59.4 & yes & 66.5 \\
\hline & & & & no & 33.5 \\
\hline
\end{tabular}

Using linear regression analysis, we examined the effect of seven factors, which were the size of the organization in terms of number of employees (NUM_EMPLOY), legal form of the company (LEGAL_F), Sector of the national economy the company operates in (SECTOR), share of foreign capital in the ownership structure (FOR_CAP), change of the overall economic situation of the company compared to the previous year (ECON_SIT), final economic performance of the company (LOSS/PROF) and existence of HR unit in the organisational structure of the company (HR_UNIT) on the implementation of diversity management in the company. The summary of the regression model is shown in table 4 . As can be seen, the models explain only from $15 \%$ (model 4 ) to $20 \%$ (model 2 ) of overall variability, therefore the results need to be approached with due caution.

Table 4. Regression Models Summary

\begin{tabular}{|l|c|c|c|c|c|}
\hline Model & R Square & F Change & df1 & df2 & Sig. F Change \\
\hline DP_I & 0.165 & 7.627 & 7 & 270 & 0.000 \\
\hline DP_B & 0.196 & 8.018 & 7 & 270 & 0.000 \\
\hline DP_IP & 0.194 & 8.017 & 7 & 270 & 0.000 \\
\hline DP_WC & 0.149 & 6.167 & 7 & 270 & 0.000 \\
\hline DP_SN & 0.153 & 6.601 & 7 & 270 & 0.000 \\
\hline DP_BQP & 0.136 & 5.614 & 7 & 270 & 0.000 \\
\hline
\end{tabular}

Based on the results of the linear regression we conclude the number of employees (NUM_EMPLOY) influences the procedural part of the diversity management implementation (DP_I) and the work climate (DP_WC). The bigger the organisation, the more positive attitude towards the diversity management implementation, which seems to be accompanied with better work climate. Another important background factor effecting the adopting of diversity management approach in Slovakia is the share of the foreign capital in the ownership structure of the companies (FOR_CAP). It influences the perception of the diversity management implementation benefits (DP_B) and problems (DP_IP) as well as the perception of the quality of work climate (DP_WC). Companies with the higher share of the foreign capital in their ownership structure perceive the diversity management 
implementation benefits more positively when compared to domestic companies and they usually perceive the implementation of diversity management as less difficult than the companies with no or low share of foreign capital in their ownership structure. Companies, in which HR unit is a part of their organisational structure, have more positive attitude towards the implementation of diversity management (DP_I). Another interesting finding is that the companies seem to focus on the special needs of their employees (DP_SN) when their economic situation (ECON_SIT) is good and they are able to generate profit (table 5).

Other factors (legal form and sector of national economy) seem to have no effect on the adopting of the diversity management approach in the companies in Slovakia.

Table 5. Effect of Background Factors

\begin{tabular}{|l|c|c|c|c|c|c|}
\hline & DP_I & DP_B & DP_IP & DP_WC & DP_SN & DP_BQP \\
\hline (Constant) & 0.000 & 0.000 & 0.000 & 0.000 & 0.000 & 0.000 \\
\hline NUM_EMPLOY & $* * 0.007$ & 0.295 & 0.674 & $* 0.039$ & 0.410 & 0.586 \\
\hline LEGAL_F & 0.115 & 0.453 & 0.942 & 0.154 & 0.320 & 0.810 \\
\hline SECTOR & 0.639 & 0.331 & 0.581 & 0.903 & 0.912 & 0.488 \\
\hline FOR_CAP & 0.137 & $* 0.028$ & $* 0.047$ & $* 0.044$ & 0.165 & 0.619 \\
\hline ECON_SIT & 0.379 & 0.888 & 0.277 & 0.226 & $* 0.032$ & 0.256 \\
\hline LOSS/PROF & 0.241 & 0.352 & 0.193 & 0.981 & $* * 0.003$ & 0.668 \\
\hline HR_UNIT & $* * 0.007$ & 0.967 & 0.985 & 0.715 & 0.701 & 0.440 \\
\hline
\end{tabular}

Note: ${ }^{* *} \mathrm{p}<0.001 ; * * \mathrm{p}<0.01 ; * \mathrm{p}<0.05$

\section{Conclusion}

The study theoretically contributes to the research focused on the factors influencing the implementation of the diversity management in the countries of the Central and Eastern Europe, in which this topic is still relatively underdeveloped.

As for practical implications, this study examined factors impacting the implementation of diversity management and it focused especially on the link between the selected background factors (the size of the company in terms of number of employees, legal form of the company, sector of the national economy the company operates in, share of foreign capital in the ownership structure of a company, change of the overall economic situation of the company compared to the previous year, final economic performance of the company and the existence of HR unit in the organisational structure of a company) and the aspects of adopting of diversity management approach in the companies in Slovakia.

While this study provides useful findings, it also has limitations that call for further research. The first restriction of fully applying our results is a context limitation and therefore a perfect fit for research results are especially decision makers in the companies of Visegrad region countries (Slovakia, Czech Republic, Poland and Hungary). Furthermore, our findings can be found interesting by the policy makers in the countries, where the attitude towards the implementation of diversity management is similar to the one applied in above mentioned countries.

Further research could be focused on other factors, which could have an influence on the diversity management implementation (such as leadership style and board diversity). 


\section{References}

1. Wentling, R. M., Palma- Rivas, N. (2000). Current status of diversity initiatives in selected multinational corporations. Human Resource Development Quarterly, 11(1), $35-60$.

2. Bryan, J. H. (1999). The Diversity Imperative Managing people welt is the top priority. Executive Excellence, 16, 6-6.

3. Torres, C., Bruxelles, M. (1992). Capitalizing on global diversity. HR Magazine, 37, 3030 .

4. Allen, R., Dawson, G., Wheatley, K., White, C. S. (2004). Diversity Practices: Learning Responses for Modern Organisation. Development and Learning in Organisations: An Int. J, 18(6), 13-15.

5. Köllen, T. (2019). Diversity management: A critical review and agenda for the future. Journal of Management Inquiry, Article Number 1056492619868025.

6. Foldy, E. (2002). Managing diversity: power and identity in organizations. In I. Aaltio and A. J. Mills (Eds.), Gender, identity and the culture of organizations (pp. 92-112). London: Routledge.

7. Dennissen, M., Benschop, Y., van den Brink, M. (2019). Diversity networks: networking for equality?. British Journal of Management, 30(4), 966-980.

8. Cox, T. H., \& Blake, S. (1991). Managing cultural diversity: Implications for organizational competitiveness. Academy of Management Perspectives, 5(3), 45-56.

9. Otaye-Ebede, L. (2019). Antecedents and outcomes of managing diversity in a UK context: test of a mediation model. The International Journal of Human Resource Management, 30(18), 2605-2627.

10. Watson, W. E., Kumar, K., Michaelsen, L. K. (1993). Cultural diversity's impact on interaction process and performance: Comparing homogeneous and diverse task groups. Academy of management journal, 36(3), 590-602.

11. Saona, P., Muro, L., San Martín, P. (2018, June). Board of Director Gender Diversity and Its Impact on Earnings Management: An Empirical Analysis for Selected European Firms. 31st Australasian Finance and Banking Conference.

12. Bernile, G., Bhagwat, V., Yonker, S. (2018). Board diversity, firm risk, and corporate policies. Journal of Financial Economics, 127(3), 588-612.

13. Hassan, R., \& Marimuthu, M. (2017). Does corporate diversity really matter in the plantation sector? Empirical evidence from a world Islamic leading country and market reaction. International Journal of Financial Studies, 5(3), 17.

14. Jebran, K., Chen, S., \& Zhang, R. (2020). Board diversity and stock price crash risk. Research in International Business and Finance, 51, Article Number 101122.

15. Graafland, J. (2020). Women in management and sustainable development of SMEs: Do relational environmental management instruments matter?. Corporate Social Responsibility and Environmental Management.

16. White, R. D. (1999). Managing the diverse organization: the imperative for a new multicultural paradigm. Public Administration \& Management: An Interactive Journal, 4(4), 469-493.

17. Goetz, S.J. (2001). Workforce diversity, Emporia State University.

18. Vaske, J. J., Beaman, J., Sponarski, C. C. (2017). Rethinking internal consistency in Cronbach's alpha. Leisure Sciences, 39(2), 163-173. 